\title{
Recovery from Desensitization of Neuronal Nicotinic Acetylcholine Receptors of Rat Chromaffin Cells Is Modulated by Intracellular Calcium through Distinct Second Messengers
}

\author{
L. Khiroug, ${ }^{1}$ Elena Sokolova, ${ }^{2}$ R. Giniatullin, ${ }^{2}$ R. Afzalov, ${ }^{2}$ and A. Nistri ${ }^{1}$ \\ ${ }^{1}$ Biophysics Sector and Istituto Nazionale di Fisica della Materia Unit, International School for Advanced Studies (SISSA), \\ 34013 Trieste, Italy, and '2Department of Physiology, Kazan Medical University, 420000 Kazan, Russia
}

The mechanisms through which changes in intracellular $\mathrm{Ca}^{2+}$ concentration $\left(\left[\mathrm{Ca}^{2+}\right]_{\mathrm{i}}\right)$ might influence desensitization of neuronal nicotinic receptors (nAChRs) of rat chromaffin cells were investigated by simultaneous patch-clamp recording of membrane currents and confocal microscopy imaging of $\left[\mathrm{Ca}^{2+}\right]_{\mathrm{i}}$ induced by nicotine. Increases in $\left[\mathrm{Ca}^{2+}\right]_{i}$ that were induced by membrane depolarization or occurred spontaneously did not influence inward currents elicited by focally applied test pulses $(10 \mathrm{msec})$ of nicotine, indicating that raised $\left[\mathrm{Ca}^{2+}\right]_{i}$ per se did not trigger desensitization of nAChRs. Desensitization of nAChRs, evoked by 2 sec focal application of nicotine, which largely raised $\left[\mathrm{Ca}^{2+}\right]_{\mathrm{i}}$, was not affected by intracellular application of agents that activate or depress protein kinase $C$ (PKC) or A (PKA) or inhibit phosphatase 1, 2 A and B. Conversely, recovery from desensitization was facilitated by the phorbol ester phorbol 12-myristate 13-acetate (PMA) or the phos- phatase 2 B inhibiting complex of cyclosporin A-cyclophilin A, whereas it was impaired by the broad spectrum kinase inhibitor staurosporine. The effects of PMA or staurosporine were prevented by the intracellularly applied $\mathrm{Ca}^{2+}$ chelator BAPTA. The adenylate cyclase activator forskolin accelerated recovery, whereas the selective PKA antagonist Rp-cAMPS had an opposite effect. The action of staurosporine and Rp-cAMPS on recovery from desensitization was additive. It is proposed that when nAChRs are desensitized, they become susceptible to modulation by $\left[\mathrm{Ca}^{2+}\right]_{\mathrm{i}}$ via intracellular second messengers such as serine/threonine kinases and calcineurin. Thus, the phosphorylation state of neuronal nAChRs appears to regulate their rate of recovery from desensitization.

Key words: protein kinase C; protein kinase A; calcineurin; phosphatase; calcium imaging; nicotine
Calcium ions $\left(\mathrm{Ca}^{2+}\right)$ have a multifactorial role in the function of nicotinic acetylcholine receptors (nAChRs). (1) They readily permeate through open channels, thus generating in the case of neuronal nAChRs $\sim 2.5-5.0 \%$ of the total membrane current (Zhou and Neher, 1993; Vernino et al., 1994); (2) they modulate channel opening (Mulle et al., 1992; Vernino et al., 1994; Amador and Dani, 1995); and (3) they control desensitization (Manthey, 1966; Magazanik and Vyskocil, 1970) via an intracellular site action as demonstrated on muscle nAChRs (Miledi, 1980; Chestnut, 1983). The process of desensitization has recently attracted increasing attention because of its ability to influence synaptic transmission over extended periods, thus controlling the time course of synaptic events and enabling sustained changes in efficacy of synaptic transmission (Jones and Westbrook, 1996). An interesting model that is used to further investigate the link between $\left[\mathrm{Ca}^{2+}\right]_{\mathrm{i}}$ and desensitization of $\mathrm{nAChRs}$ is the chromaf-

Received Dec. 15, 1997; revised Jan. 16, 1998; accepted Jan. 21, 1998.

This work was supported by grants to A.N. from Istituto Nazionale di Fisica della Materia (INFM), Consiglio Nazionale delle Ricerche, and Ministero dell' Università e della Ricerca Scientifica e Tecnologica. R.G. and M.T. are grateful to the Russian Foundation for Fundamental Research (RFFR) for financial support. L. K. gratefully acknowledges a $\mathrm{PhD}$ studentship from the International Center for Genetic Engineering and Biotechnology (ICGEB). We thank Dr. Cristina Marchetti and Dr. Silvia Di Angelantonio for taking part in some experiments and Dr. Massimo Righi for cell culture preparation. The cyclosporin A/cyclophilin A complex and its inactive analog were generously donated by Dr. H. W. Boddeke, Novartis, Basle, Switzerland.

Correspondence should be addressed to A. Nistri, Biophysics Sector and Istituto Nazionale di Fisica della Materia Unit, International School for Advanced Studies (SISSA), Via Beirut 4, 34014 Trieste, Italy.

Copyright (C) 1998 Society for Neuroscience $0270-6474 / 98 / 182458-09 \$ 05.00 / 0$ fin cell of the adrenal medulla, which receives a major cholinergic input from the splanchnic nerve to release catecholamines into the bloodstream. Chromaffin cells possess neuronal $\mathrm{nAChRs}$ that comprise heterologous assemblies of $\alpha_{3}, \alpha_{5}$, and $\beta_{4}$ subunits (Criado et al., 1992; Campos-Caro et al., 1997), as well as a distinct homomeric $\alpha_{7}$ receptor inhibited by $\alpha$-bungarotoxin (Garcia-Guzman et al., 1994). On these cells it was recently observed that the duration of a nicotine-induced rise in intracellular $\mathrm{Ca}^{2+}$ concentration $\left[\mathrm{Ca}^{2+}\right]_{\mathrm{i}}$ determined how long $\mathrm{nAChRs}$ took to recover from desensitization (Khiroug et al., 1997b). $\left[\mathrm{Ca}^{2+}\right]_{i}$, which rose because of its transmembrane influx via nAChRs, apparently did not influence the onset of desensitization; rather it strictly controlled the duration of this phenomenon.

These findings prompted a number of questions. (1) Can a large rise in $\left[\mathrm{Ca}^{2+}\right]_{i}$ per se in conjunction with activation of nAChRs by a nondesensitizing dose of nicotine induce desensitization? This is an important issue, because one would expect substantial variations in $\left[\mathrm{Ca}^{2+}\right]_{\mathrm{i}}$ to occur physiologically as a result of influx (attributable to repetitive firing) or internal release or both (Berridge, 1997). (2) Does $\mathrm{Ca}^{2+}$ exert its role on chromaffin cells via those intracellular messengers that have been shown to regulate desensitization of other nAChRs? For example, candidates to fulfill this role are the cyclic AMP-dependent protein kinase (PKA), which increases the rate of rapid desensitization of Torpedo nAChRs (Huganir et al., 1986), or protein kinase $\mathrm{C}(\mathrm{PKC})$, which enhances desensitization of neuronal nAChRs of sympathetic ganglia (Downing and Role, 1987). Recent experiments performed on skeletal muscle nAChRs have suggested that the rate of recovery from desensitization is actu- 
ally dependent on the balance between PKC and phosphatases (Hardwick and Parsons, 1996), especially calcineurin, which is recognized as a major determinant of ligand-gated receptor function (Yakel, 1997).

Using simultaneous recording of whole-cell currents and $\left[\mathrm{Ca}^{2+}\right]_{\mathrm{i}}$ imaging by confocal laser scanning microscopy on rat chromaffin cells, we compared the effects of $\left[\mathrm{Ca}^{2+}\right]_{i}$ rises (induced by a desensitizing dose of nicotine, membrane depolarization, or spontaneous occurrence) on nAChR sensitivity. Furthermore, we examined the action of relatively selective activators or inhibitors of the second messenger systems outlined above on nAChR desensitization.

\section{MATERIALS AND METHODS}

Combined confocal microscopy and patch-clamp recordings from cultured cells were performed as published elsewhere (PC12 cells, Khiroug et al., 1997a; rat chromaffin cells, Khiroug et al., 1997b).

Cell culture. Rat chromaffin medullary cells were prepared according to Brandt et al. (1976). Briefly, ether-anesthetized female rats (200-250 gm body weight) were decapitated, and their adrenal glands were removed, dissected free of the cortex, and rinsed in a medium containing (in mM): $\mathrm{NaCl} 137, \mathrm{KCl} 3, \mathrm{Na}_{2} \mathrm{HPO}_{4}$ 0.7, HEPES 25, glucose 10, and 350 $\mathrm{U} / \mathrm{ml}$ of penicillin and streptomycin, $\mathrm{pH}$ 7.2. Cells were dissociated by drawing adrenal tissue fragments gently up and down a Pasteur pipette every $15-20 \mathrm{~min}$ after treating them at $37^{\circ} \mathrm{C}$ with collagenase $\mathrm{A}$ and DNase I $(0.5 \mathrm{U} / \mathrm{ml}$ and $10 \mu \mathrm{g} / \mathrm{ml}$, respectively). After centrif ugation and rinsing with the HEPES-buffered medium, cells were suspended in DMEM containing $10 \%$ fetal calf serum, plated on poly-lysine $(1.25$ $\mathrm{mg} / \mathrm{ml}$ )-coated petri dishes, and cultured for $1-2 \mathrm{~d}$ under a $5 \% \mathrm{CO}_{2}$ containing atmosphere.

Whole-cell patch-clamp recordings. Cell-containing culture dishes (mounted on the stage of an inverted Nikon microscope) were superfused $(5-10 \mathrm{ml} / \mathrm{min}$ ) with control saline solution containing (in $\mathrm{mM}$ ): $\mathrm{NaCl} 132, \mathrm{KCl} 5, \mathrm{MgCl}_{2} 1, \mathrm{CaCl}_{2}$ 2, glucose 10, HEPES 10, pH adjusted to 7.4 with $\mathrm{NaOH}$. Patch pipettes were filled with (in $\mathrm{mM}$ ): $\mathrm{CsCl} 120$, HEPES $20, \mathrm{MgCl}_{2} 1, \mathrm{Mg}_{2} \mathrm{ATP}_{3} 3$. When experiments involved confocal $\left[\mathrm{Ca}^{2+}\right]_{\mathrm{i}}$ imaging, the $\mathrm{Ca}^{2+}$-sensitive dye fluo-3 was added to this pipette solution. In some electrophysiological experiments the $\mathrm{Ca}^{2+}$ chelator BAPTA was added instead. The $\mathrm{pH}$ of the pipette solution was always adjusted to 7.2 with $\mathrm{CsOH}$. Activators or inhibitors of intracellular second messengers were diluted with the pipette solution for intracellular application. Unless indicated otherwise, cells were voltage-clamped at $-70 \mathrm{mV}$. After the whole-cell condition was obtained, a $10 \mathrm{~min}$ period of stabilization was allowed before membrane currents were recorded. The current responses were filtered at $1 \mathrm{kHz}$, acquired on the hard disk of a PC using pCLAMP software, and measured in terms of time to peak, amplitude, and exponential decay.

Imaging of $\left[\mathrm{Ca}^{2+}\right]_{i}$. For $\left[\mathrm{Ca}^{2+}\right]_{\mathrm{i}}$ imaging in the visible light range, the $\mathrm{Ca}^{2+}$-sensitive dye fluo-3 (Minta et al., 1989) was used. Fluo-3 (cell impermeant form, pentapotassium salt) was applied via the patch pipette $(25 \mu \mathrm{M})$. Emission of fluo-3 was induced by an Ar-Kr laser (488 nm) and detected by the photomultiplier tube of a MultiProbe 2001 confocal laser scanning microscope (Molecular Dynamics, Sunnyvale, CA) using a combination of $510 \mathrm{~nm}$ high-pass and $530 \pm 30 \mathrm{~nm}$ bandpass filters. This approach can provide high temporal and spatial resolution of $\left[\mathrm{Ca}^{2+}\right]_{\mathrm{i}}$ signals in various subcellular compartments (Khiroug et al., 1997b), even though this facility was not exploited in the present study. No dye bleaching was detected under the present conditions. Fluorescent signals were digitized over the whole central optical section as $64 \times 32$ pixel images in the 32-line rapid scan mode (temporal resolution, $320 \mathrm{msec}$ per scan; pixel size, $0.6 \mu \mathrm{m}$; confocal aperture, $200 \mu \mathrm{m}$ ), thus yielding a $38 \times$ $19 \mu \mathrm{m}$ image. $\left[\mathrm{Ca}^{2+}\right]_{\mathrm{i}}$ transients were analyzed in terms of rise time $\left(10-90 \%\right.$ of peak amplitude), fractional amplitude $\left(\Delta F / F_{0}\right.$, where $F_{0}$ is the baseline fluorescence level, and $\Delta F$ is the rise over the baseline), and percentage decay at $30 \mathrm{sec}$ from the beginning of $2 \mathrm{sec}$ nicotine application.

Data analysis, drug application, and experimental protocols. Data are presented as mean $\pm \operatorname{SEM}(n=$ number of cells), with statistical significance assessed with one-way ANOVA test (for nonparametric data) or unpaired $t$ test (for normally distributed data). A value of $p=$ 0.05 was accepted as indicative of a statistically significant difference. $(-)$-Nicotine (hydrogen tartrate salt) was diluted in control saline solu- tion at a final concentration of $1 \mathrm{~mm}$ and delivered by pressure application (10-20 psi via a Picospritzer II) from glass micropipettes positioned $\sim 15 \mu \mathrm{m}$ away from the recorded cell. Assuming an approximate fourfold dilution of agonist applied by a brief pressure pulse (Giniatullin et al., 1996), the nonequilibrium concentration of nicotine at membrane level would thus be $\sim 250 \mu \mathrm{M}$, a value nearly 10 times larger than the estimated concentration producing half-maximal response (Boyd, 1987).

Desensitization was studied with a classical protocol (Katz and Thesleff, 1957) consisting of repeated test applications $(10-20 \mathrm{msec})$ of nondesensitizing doses of agonist to assess the sensitivity of nAChRs before and after the conditioning (desensitizing) dose of the same drug. Test doses were usually applied at $30 \mathrm{sec}$ intervals to ensure full return of $\left[\mathrm{Ca}^{2+}\right]_{i}$ to baseline after each test pulse and the absence of any cumulative desensitization. With such constraints, shorter intervals (15 $\mathrm{sec})$ could therefore be used only occasionally. The conditioning application of nicotine ( $2 \mathrm{sec}$ from the same pipette) elicited a rapidly fading inward current. The following parameters of desensitization were measured: the ratio (expressed in percentage values) between the current amplitude at the end of the $2 \mathrm{sec}$ nicotine pulse and its peak amplitude $\left(A_{\text {end }} / A_{\text {peak }}\right)$, which provided an estimate of the extent of desensitization, the time constants of biexponential current decay from its peak during 2 sec nicotine pulse $\left(\tau_{1}\right.$ and $\left.\tau_{2}\right)$ to characterize the rate of onset of desensitization, and the amplitude of currents (elicited by test pulses of nicotine) at fixed times after the conditioning application to assess the recovery of nAChRs from desensitization.

\section{RESULTS}

nAChR-mediated responses during raised $\left[\mathrm{Ca}^{2+}\right]_{\mathrm{i}}$

An example of the standard protocol to induce nAChR desensitization is shown in Figure $1 A$, which illustrates combined current (Fig. $1 A b)$ and $\left[\mathrm{Ca}^{2+}\right]_{\mathrm{i}}$ (Fig. $1 A a$ ) measurements in a cell tested with $10 \mathrm{msec}$ pulses of nicotine. Test pulses were applied at $30 \mathrm{sec}$ intervals to elicit stable control responses, the last one of which is shown in left panel of Figure $1 A$. The conditioning $2 \mathrm{sec}$ pulse of the same agonist induced current fading to $22 \%$ level of the peak at the end of the pulse, a phenomenon attributable to nAChR desensitization (Khiroug et al., 1997b). After the conditioning pulse, the test pulses were resumed at the same rate to monitor the time course of $\mathrm{nAChR}$ recovery from desensitization. In this case, $30 \mathrm{sec}$ later there was $29 \%$ depression of the test current, whereas $\left[\mathrm{Ca}^{2+}\right]_{\mathrm{i}}$ decayed by $47 \%$ from $1.2 \Delta F / F_{0}$ peak value; test current recovery was obtained after $1.5 \mathrm{~min}$. The plot of Figure $1 C$ shows pooled data for recovery of test pulses after the conditioning pulse ( $n=10$; inclusive of cells tested at 15 or $30 \mathrm{sec}$ intervals). For instance, $30 \mathrm{sec}$ after $2 \mathrm{sec}$ nicotine application the test current amplitude was $35 \pm 6 \%$, a result that accords with our previous study (Khiroug et al., 1997b). The time course of current recovery could be fitted by a monoexponential function (44 sec time constant) as shown in Figure $1 C$.

Our previous investigation has taken as an index of recovery from desensitization the test current amplitude at various intervals from the conditioning pulse. This approach relies on the assumption that a rise in $\left[\mathrm{Ca}^{2+}\right]_{i}$ per se does not downregulate receptor activity independently of desensitization, because manipulation of $\left[\mathrm{Ca}^{2+}\right]_{i}$ had no effect on either the onset of $\mathrm{nAChR}$ desensitization or the peak amplitude of nicotine conditioning currents (Khiroug et al., 1997b). Nevertheless, it is important to ascertain whether a large rise in $\left[\mathrm{Ca}^{2+}\right]_{\mathrm{i}}$ evoked, for example, by step depolarization of the membrane might transiently affect nondesensitizing responses to nicotine. This possibility was explored using 0.5-2 sec depolarizing steps (from the standard holding potential to $0 \mathrm{mV}$ ) to obtain a large $\left[\mathrm{Ca}^{2+}\right]_{\mathrm{i}}$ rise without applying a desensitizing pulse of nicotine. Figure $1 B a, b$ shows an example of the effects produced by this protocol on $\left[\mathrm{Ca}^{2+}\right]_{i}$ and nondesensitizing test currents induced by $10 \mathrm{msec}$ pulses of nicotine. A single voltage step (applied at the time indicated by 


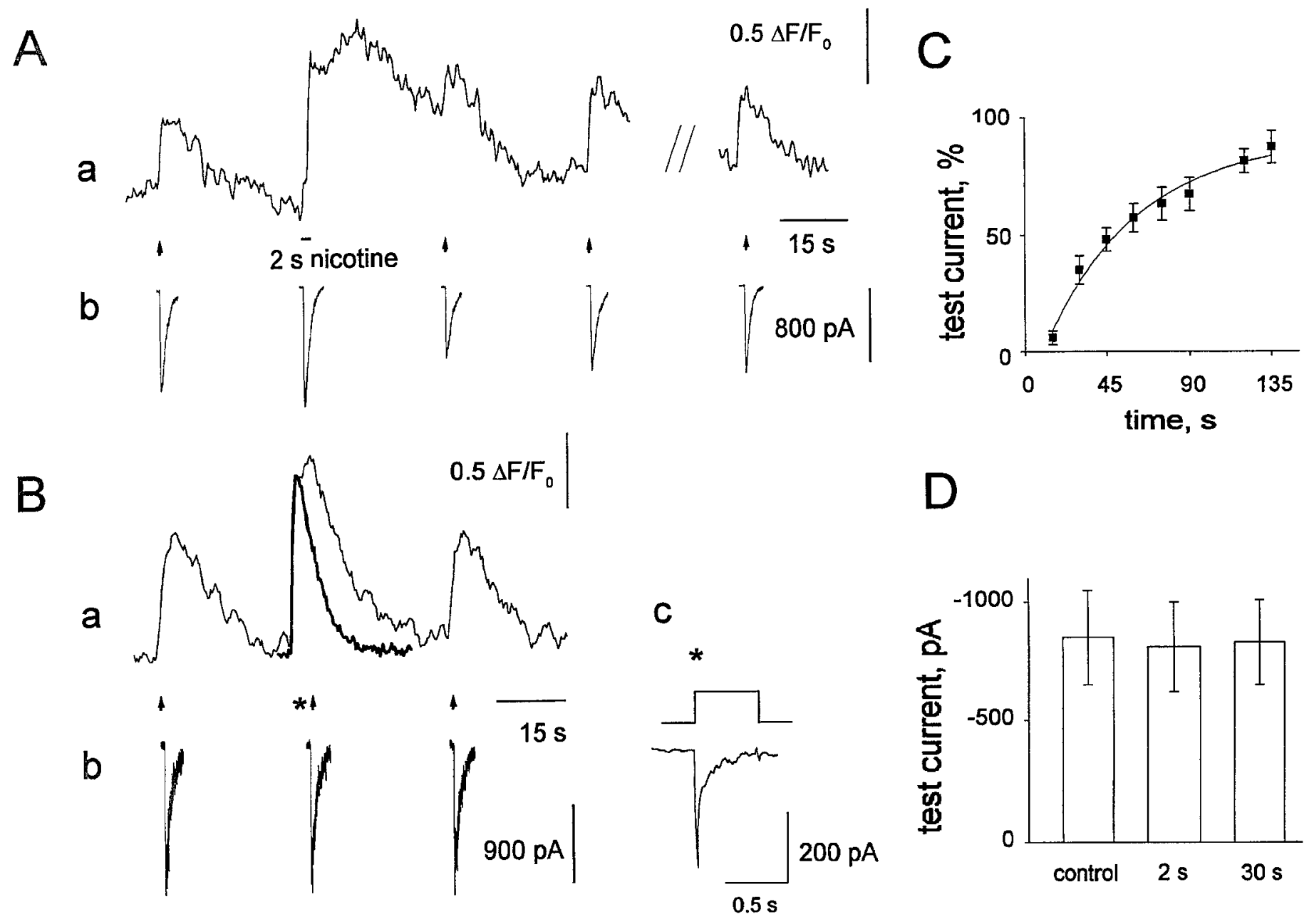

Figure 1. Combined recording (fluo-3-containing pipette) of membrane currents and $\left[\mathrm{Ca}^{2+}\right]_{\mathrm{i}}$ from chromaffin cells. $A$, The conditioning pulse of nicotine $\left(2 \mathrm{sec}\right.$; horizontal bar) produced a fading current response $(b)$ and a persistent increase in $\left[\mathrm{Ca}^{2+}\right]_{\mathrm{i}}(a)$, with subsequent depression of test current amplitude induced by $10 \mathrm{msec}$ nicotine pulses $(b$, arrowheads) attributable to desensitization of nAChRs. Break in trace corresponds to 30 sec. $B$, A 0.5 sec depolarization of membrane potential (from -70 to $0 \mathrm{mV}$ ) induces a relatively large elevation in $\left[\mathrm{Ca}^{2+}\right]_{\mathrm{i}}$ thick trace in $\mathrm{Ba}$ ) associated with a transient inward current (see $B c$ ). When a similar depolarization is applied (see *) $2 \mathrm{sec}$ before the test pulse of nicotine (thin trace, arrowheads), no depression of the nicotine-induced current $(b)$ is present. Thirty seconds later, test current amplitude is also not different from control. $C$, Average time course of recovery from desensitization (evoked by $2 \mathrm{sec}$ nicotine application) obtained from a sample of 10 cells in control conditions can be fitted with an exponential function $(\tau=44 \mathrm{sec})$. $D$, Average amplitude of test currents 2 and $30 \mathrm{sec}$ after voltage step is not different from control $(n=11)$.

asterisk in $B$ ) evoked an inward current, presumably attributable to influx of $\mathrm{Na}^{+}$and $\mathrm{Ca}^{2+}$ (note fast time base record in Fig. $1 B c$ ) and an associated $\left[\mathrm{Ca}^{2+}\right]_{\mathrm{i}}$ response (see thick line in Fig. $1 B a$ ). The latter is superimposed for comparison on the response (thin line; middle) observed when the voltage step was followed closely by a nicotine test pulse. Two seconds after the depolarizing step when $\left[\mathrm{Ca}^{2+}\right]_{\mathrm{i}}$ had not yet returned to baseline, nicotine evoked a current response with no apparent depression in amplitude that remained unchanged even $30 \mathrm{sec}$ later. Histograms of Figure $1 D$ summarize the data from 11 cells. These results thus indicate that a large, transient rise in $\left[\mathrm{Ca}^{2+}\right]_{\mathrm{i}}$ per se did not induce early or late effects on nicotine-mediated nondesensitizing currents.

Another approach to examining possible cross talk between nAChRs and $\left[\mathrm{Ca}^{2+}\right]_{\mathrm{i}}$ was to study persistent $\left[\mathrm{Ca}^{2+}\right]_{\mathrm{i}}$ elevations (accompanied by substantial inward currents) (D'Andrea and Thorn, 1996) that occurred spontaneously in a few cells. The example of Figure $2 A$ shows that two test pulses of $10 \mathrm{msec}$ nicotine (at $30 \mathrm{sec}$ intervals) evoked reproducible $\left[\mathrm{Ca}^{2+}\right]_{\mathrm{i}}$ rises
$(A a)$ and inward currents $(A b)$; the second of these two responses was followed by a spontaneous inward current (see arrow pointing to its start in $A b$ ) with abrupt onset and associated persistent increase in $\left[\mathrm{Ca}^{2+}\right]_{\mathrm{i}}$ (arrow in $\left.A a\right)$. When next test pulse of nicotine was applied $26 \mathrm{sec}$ later and $\left[\mathrm{Ca}^{2+}\right]_{\mathrm{i}}$ remained elevated, the nicotine-induced inward current was unchanged, arising from a shallow shift in current baseline $(-205 \mathrm{pA})$ attributable to the spontaneous inward current (compare takeoff of nicotine current from dotted baseline). After an additional $30 \mathrm{sec}$ interval when $\left[\mathrm{Ca}^{2+}\right]_{\mathrm{i}}$ had declined by $67 \%$ from its peak value, the nicotine current remained unaffected. Data from seven cells are summarized in Figure $2 B$, in which the test current amplitude near the peak of or $30 \mathrm{sec}$ after a spontaneous $\left[\mathrm{Ca}^{2+}\right]_{\mathrm{i}}$ wave is compared with control. These observations confirm that even a robust and persistent $\left[\mathrm{Ca}^{2+}\right]_{\mathrm{i}}$ rise (including the one close to the inner side of the cell membrane) (Khiroug et al., 1997b) did not interfere with the normal operation of activated nAChRs, unless they had been desensitized previously (see example in Fig. 1A). The present results thus suggest that such a rise by itself is not a 


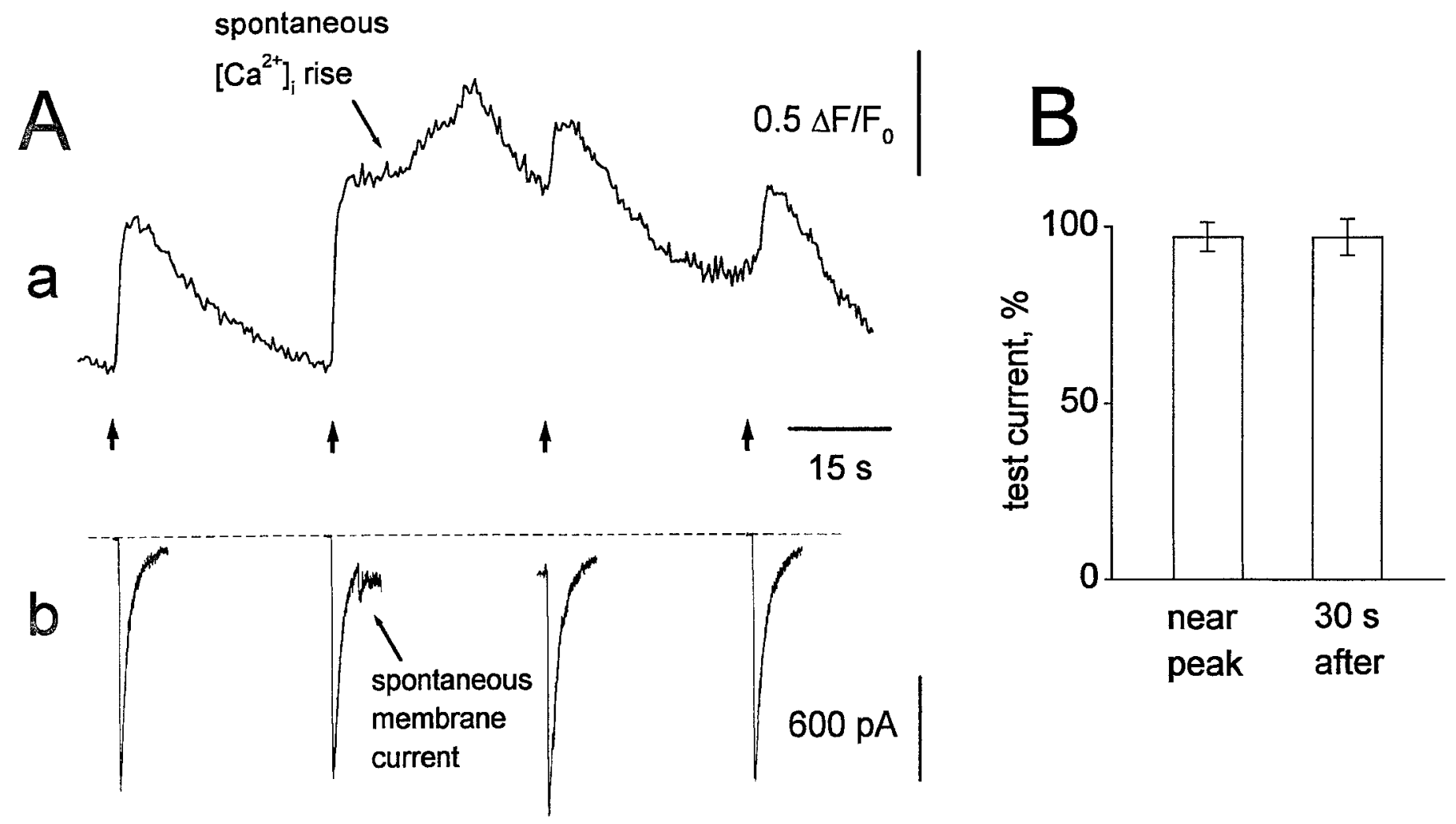

Figure 2. Spontaneous $\left[\mathrm{Ca}^{2+}\right]_{\mathrm{i}}$ rise does not affect amplitude of test nicotine currents. $A$, Combined recording of $\left[\mathrm{Ca}^{2+}\right]_{\mathrm{i}}(a)$ and membrane currents (b) induced by $10 \mathrm{msec}$ test applications of nicotine (short arrows) before (left), during (middle), or after (right) the spontaneous increase in [Ca $\left.{ }^{2+}\right]_{i}$ (indicated by the long arrow in $a$ ). Note onset of the persistent inward current (arrow in $b$ ) accompanying the $\left[\mathrm{Ca}^{2+}\right]_{\mathrm{i}}$ increase. $B$, Data pooled from 7 cells indicate lack of change in the normalized amplitude of test currents close to the peak of, or $30 \mathrm{sec}$ after, the spontaneous $\left[\mathrm{Ca}^{2+}\right]_{\mathrm{i}}$ rise.

Table 1. Characteristics of inward current and $\left[\mathrm{Ca}^{2+}\right]_{i}$ rise evoked by 2 sec pulse of nicotine are not affected by drugs regulating protein kinase/phosphatase activity

\begin{tabular}{llcrcc} 
& $A_{\text {peak }}(\mathrm{nA})$ & $A_{\text {end }} / A_{\text {peak }}(\%)$ & $\tau_{1}(\mathrm{msec})$ & $\tau_{2}(\mathrm{msec})$ & {$\left[\mathrm{Ca}^{2+}\right]_{\mathrm{i}} \mathrm{decay}(\%)$} \\
\hline Control $(n=10)$ & $1.1 \pm 0.2$ & $8 \pm 5$ & $110 \pm 20$ & $660 \pm 100$ & $50 \pm 9$ \\
PMA $(n=14)$ & $1.2 \pm 0.2$ & $11 \pm 2$ & $90 \pm 10$ & $760 \pm 140$ & $44 \pm 7$ \\
Staurosporine $(n=13)$ & $0.9 \pm 0.2$ & $12 \pm 1$ & $140 \pm 20$ & $730 \pm 100$ & $40 \pm 6$ \\
Forskolin $(n=4)$ & $1.0 \pm 0.2$ & $12 \pm 7$ & $110 \pm 30$ & $620 \pm 60$ & $47 \pm 9$ \\
Rp-cAMPS $(n=10)$ & $0.8 \pm 0.2$ & $15 \pm 4$ & $80 \pm 10$ & $640 \pm 120$ & $54 \pm 13$ \\
CC complex $(n=3)$ & $1.1 \pm 0.2$ & $10 \pm 7$ & $100 \pm 10$ & $430 \pm 80$ & $58 \pm 9$ \\
Calyculin A $(n=5)$ & $1.3 \pm 0.3$ & $90 \pm 30$ & $510 \pm 50$ & $47 \pm 13$
\end{tabular}

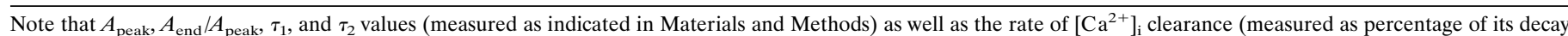
from peak value $30 \mathrm{sec}$ after the conditioning pulse of nicotine) were independent of the above treatments.

sufficient condition to produce desensitization of nAChRs. This view is also supported by our previous observation that chelation of $\left[\mathrm{Ca}^{2+}\right]_{\mathrm{i}}$ by BAPTA does not change desensitization of nAChRs (although an increase in $\left[\mathrm{Ca}^{2+}\right]_{i}$ is necessary for keeping receptors desensitized) (Khiroug et al., 1997b).

\section{Onset of nAChR desensitization was not affected by pharmacological manipulation of PKA, PKC, or phosphatases $2 \mathrm{~A}$ and $2 \mathrm{~B}$}

Intracellular messengers such as PKC, PKA, or phosphatases, which are dependent on $\left[\mathrm{Ca}^{2+}\right]_{i}$, have been reported to modulate desensitization of nAChRs in other cells (Huganir and Greengard, 1990; Levitan, 1994). It was therefore necessary to ascertain first whether the onset of desensitization of nAChRs of chromaffin cells might have been controlled by these intracellular systems. This was investigated by observing how the various parameters of inward currents induced by $2 \mathrm{sec}$ nicotine pulse and the associated $\left[\mathrm{Ca}^{2+}\right]_{\mathrm{i}}$ transients were modified by activators or inhibitors of these enzymes when applied through the patch pipette. Hence, the effects of the PKC activator PMA $(0.1 \mu \mathrm{M})$, the broad spectrum kinase inhibitor staurosporine $(0.1 \mu \mathrm{M})$, the adenylate cyclase activator forskolin $(10 \mu \mathrm{M})$, which presumably led to stimulated PKA activity, the selective PKA inhibitor RpcAMPS $(10 \mu \mathrm{M})$, the selective inhibitor of calcineurin, cyclosporin A-cyclophilin A (CC) complex (20 nM) or its inactive analogs (20 nM), or the protein phosphatase 1 and $2 \mathrm{~A}$ inhibitor calyculin A $(0.1 \mu \mathrm{M})$ were studied. As indicated in Table 1 , none of these substances affected the parameters of the nicotine current, such as $A_{\text {peak }}, A_{\text {end }} / A_{\text {peak }}, \tau_{1}$, or $\tau_{2}$, in keeping with analogous data for 
A

a

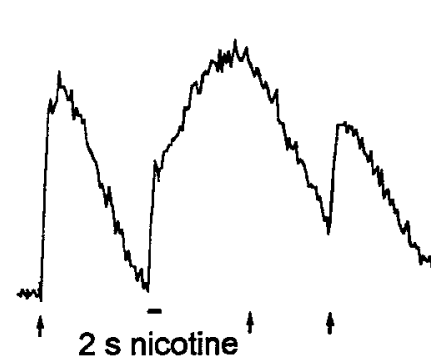

PMA

b

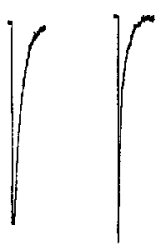

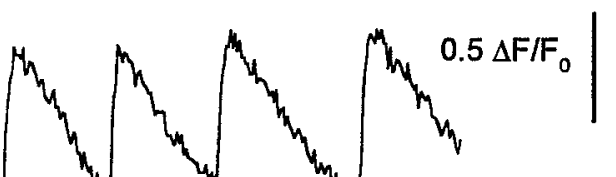

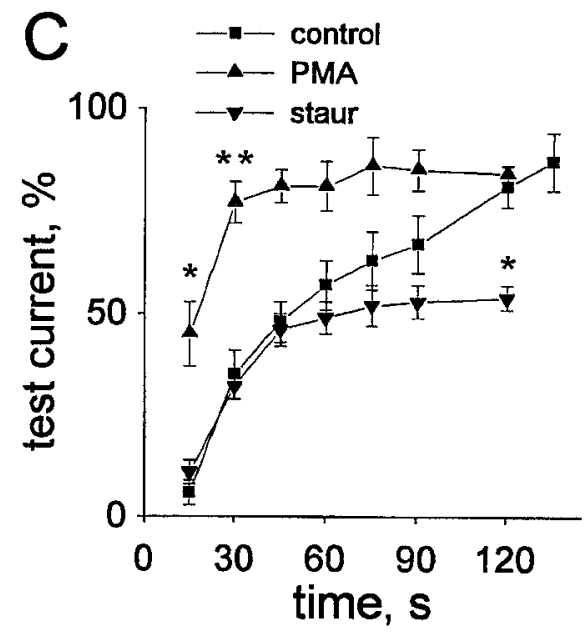

B

a

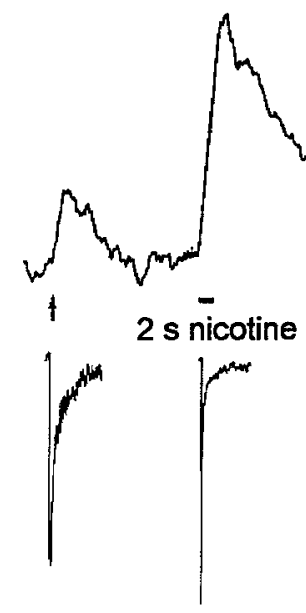

staurosporine

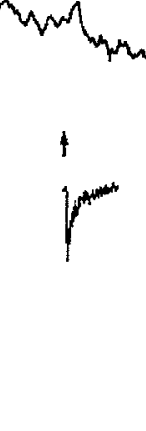

$15 \mathrm{~s}$

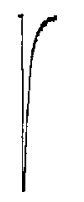

200 pA

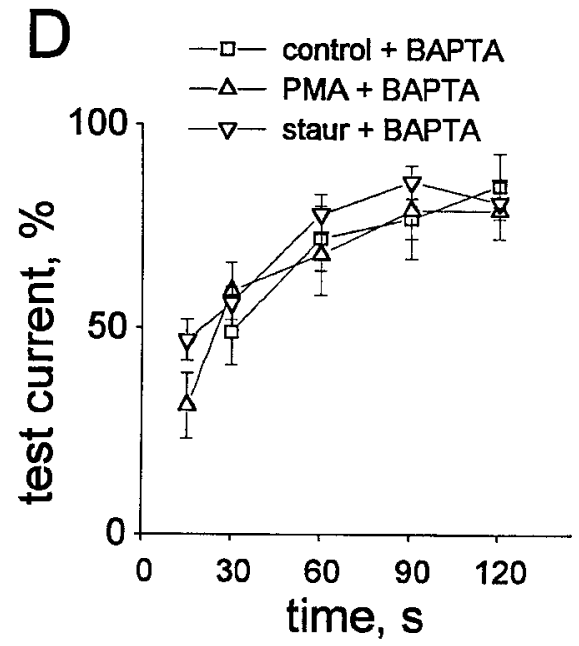

Figure 3. Effects of the phorbol ester PMA or staurosporine on recovery from desensitization of nAChRs. $A$, Membrane currents $(b)$ and $\left[C a^{2+}\right]_{\mathrm{i}}$ transients $(a)$ evoked by $10 \mathrm{msec}$ test pulses (arrows) of nicotine applied every $15 \mathrm{sec}$ from cell patched with a PMA (100 nM)-containing pipette. Note that despite a persistent increase in $\left[\mathrm{Ca}^{2+}\right]_{\mathrm{i}}$, large recovery of current amplitude already takes place $15 \mathrm{sec}$ after the desensitizing dose of nicotine. $B$, Similar protocol applied to cell patched with a pipette containing $100 \mathrm{~nm}$ staurosporine reveals incomplete recovery from desensitization despite return of $\left[\mathrm{Ca}^{2+}\right]_{\mathrm{i}}$ elevated by the $2 \mathrm{sec}$ nicotine pulse to baseline. $C$, Data pooled from 8-14 cells recorded with control (squares), PMA-containing (upward triangles), or staurosporine-containing (staur; downward triangles) pipette solution. ${ }^{*},{ }^{*} * p<0.03$ or 0.001 , respectively. $D$, In parallel experiments intracellular application of $10 \mathrm{~mm}$ BAPTA prevents effects of PMA or staurosporine, revealing their $\left[\mathrm{Ca}^{2+}\right]_{\mathrm{i}}$ dependence $(n=7-11)$.

skeletal muscle receptors (Cachelin and Colquhoun, 1989), or the degree of $\left[\mathrm{Ca}^{2+}\right]_{i}$ decay from its peak $30 \mathrm{sec}$ after the conditioning pulse of nicotine. These experiments suggest that these intracellular messengers did not affect the operation of nAChRs (as indicated by the lack of change in the $A_{\text {peak }}$ ), the induction of desensitization, or the clearance of elevated $\left[\mathrm{Ca}^{2+}\right]_{\mathrm{i}}$. It thus seemed useful to study whether the same enzyme systems might regulate the process of recovery from desensitization.

\section{Effects of a phorbol ester or staurosporine on recovery from desensitization of nAChRs}

As shown by the example in Figure $3 A$ (using a protocol similar to the one of Fig. $1 A$ ), a cell recorded when the pipette containing the PKC activator PMA $(0.1 \mu \mathrm{M})$ displayed strong fading of inward current (Fig. 3Ab) and large rise in $\left[\mathrm{Ca}^{2+}\right]_{\mathrm{i}}$ (Fig. 3Aa) during a $2 \mathrm{sec}$ nicotine pulse. Although $15 \mathrm{sec}$ after the conditioning pulse $\left[\mathrm{Ca}^{2+}\right]_{\mathrm{i}}$ had decayed by only $9 \%$ from its peak, the nicotine test current had recovered to $61 \%$. Fifteen seconds later, recovery of nicotine test current was $71 \%$, with comparable return of $\left[\mathrm{Ca}^{2+}\right]_{\mathrm{i}}$ rises. Figure $3 C$ (upward triangles) shows that on average for cells tested at 15 or $30 \mathrm{sec}$ intervals $(n=14)$ the test current was significantly less depressed at 15 or $30 \mathrm{sec}(p<0.03$ and 0.001 , respectively) than in control, and it recovered to $85 \%$ at $90 \mathrm{sec}$. The recovery curve could be fitted with a monoexponential function with $25 \mathrm{sec}$ time constant (that is approximately twofold faster than in control conditions; see above). The broad spectrum kinase inhibitor staurosporine $(0.1 \mu \mathrm{M})$ produced results opposite to those with PMA. In fact, as indicated by the example of a cell tested at $30 \mathrm{sec}$ intervals, $30 \mathrm{sec}$ after the conditioning pulse of nicotine, even if $\left[\mathrm{Ca}^{2+}\right]_{\mathrm{i}}$ had decayed by $71 \%$, the response to the test current was $35 \%$ with gradual recovery at subsequent time points. No further recovery was observed for up to $20 \mathrm{~min}$. The plot of Figure $3 C$ shows that in the presence of staurosporine (downward triangles; $n=13$; pooled data from cells tested at 15 or $30 \mathrm{sec}$ intervals), test currents at 15 or $30 \mathrm{sec}$ after conditioning were depressed as much as control ones but did not recover fully, stabilizing $90 \mathrm{sec}$ later at a level $(52 \%)$ significantly different from that in control solution $(p<$ $0.03)$. No complete recovery was ever observed during the next 


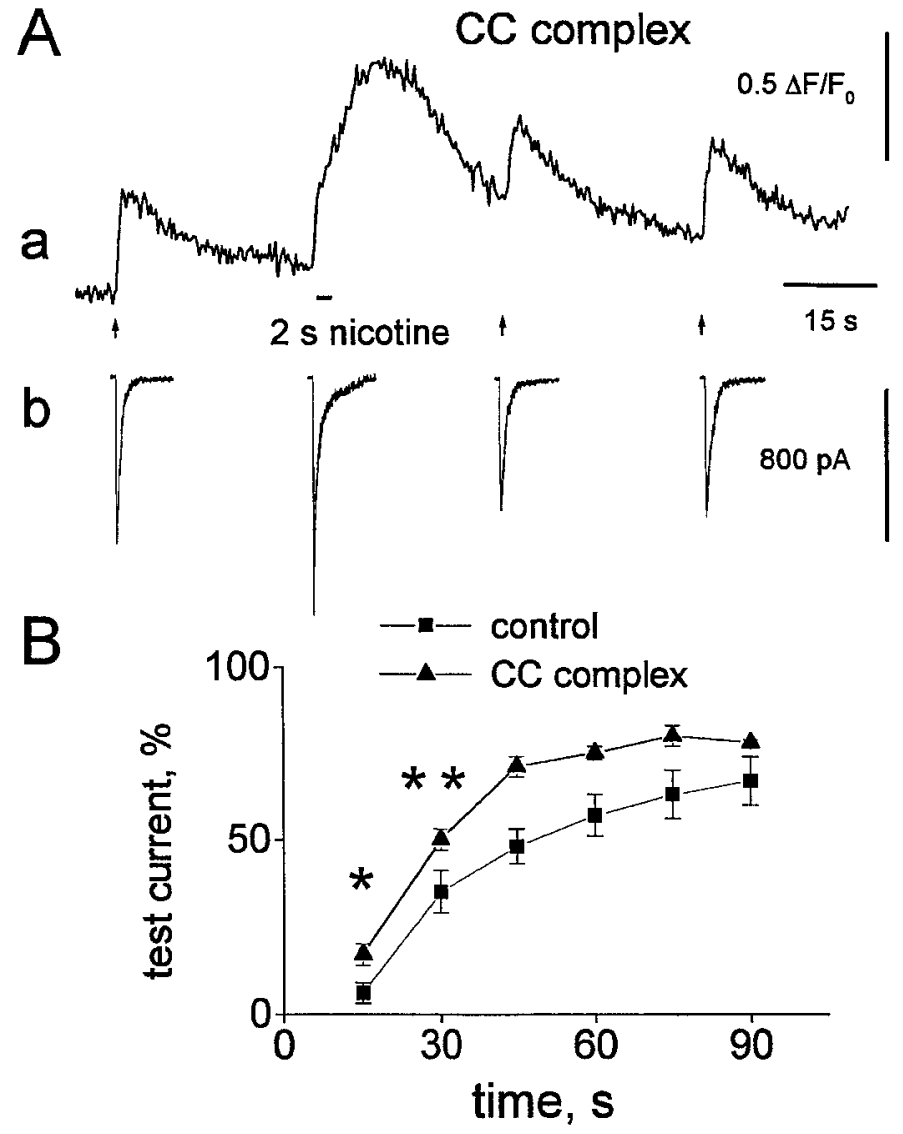

Figure 4. Acceleration of recovery from desensitization by the selective calcineurin antagonist CC complex. $A$, Membrane currents $(b)$ and $\left[\mathrm{Ca}^{2+}\right]_{\mathrm{i}}$ transients $(a)$ simultaneously recorded from a cell patched with CC complex (20 nM)-containing pipette. Note fast recovery of test current amplitude after the conditioning pulse of nicotine. $B$, Data pooled from three cells indicate an increase in recovery rate in the presence of CC complex (upward triangle). ${ }^{*}, * *=p<0.04$ and 0.05 , respectively.

15-20 min recording time. The staurosporine curve could be fitted by a monoexponential function with $20 \mathrm{sec}$ time constant; biexponential fitting of the same data yielded a slow time constant in the range of hours, which largely exceeded our observation period and led us to consider the effect as irreversible. It was observed previously that intracellular application of BAPTA strongly accelerated recovery from desensitization (Khiroug et al., 1997a,b). In the present study BAPTA (10 mM) added to the pipette solution increased recovery (e.g., at $30 \mathrm{sec}$ the test current recovered to $49 \pm 8 \%$ ), an action unchanged if either PMA or staurosporine was also present (Fig. 3D). In all three plots of Figure $3 D$ the process could be fitted by a monoexponential function with time constant in the range of 20-30 sec. These results accord with the $\left[\mathrm{Ca}^{2+}\right]_{\mathrm{i}}$ dependence of PKC activity (Hidaka and Kobayashi, 1992).

\section{Effects of phosphatase inhibitors on recovery from desensitization}

Inhibitors of phosphatases, enzymes known to modulate the activity of various ligand-gated channels (for review, see Smart, 1997; Yakel, 1997) were tested for their ability to influence recovery from desensitization of nAChRs. Figure $4 A\left(a,\left[\mathrm{Ca}^{2+}\right]_{\mathrm{i}}\right.$ signals; $b$, membrane currents) exemplifies the effects of intrapipette application of CC complex $(20 \mathrm{~nm})$ on recovery from nicotine-induced desensitization. Note that although the $2 \mathrm{sec}$ conditioning pulse of nicotine produced strong current fading and a large rise in $\left[\mathrm{Ca}^{2+}\right]_{i}$, recovery from desensitization was accelerated because $30 \mathrm{sec}$ later the amplitude of the test current was $73 \%$ of control. Average data from cells dialyzed with CC complex are shown in Figure $4 B$ (upward triangles) indicating that, for example, recovery was significantly larger than in control solution at 15 and $30 \sec (p<0.04$ and $p<0.05$, respectively) and had a smaller time constant $(19 \mathrm{sec})$. When the pipette solution contained either $0.1 \mu \mathrm{M}$ calyculin, a phosphatase 1 and $2 \mathrm{~A}$ inhibitor, or the inactive form of the CC complex $(20 \mathrm{~nm})$, there was no effect on recovery from desensitization: $30 \mathrm{sec}$ from the conditioning pulse the test current was $44 \pm 5 \%(n=5)$ or $36 \pm 5 \%$ $(n=4)$, respectively.

\section{Effects of PKA agents on recovery from desensitization}

The possible modulatory role of PKA on recovery from desensitization was studied by applying either the PKA inhibitor RpcAMPS or the adenylate cyclase activator forskolin via the patch pipette. As exemplified by the combined recordings of Figure 5, $A$ and $B$, contrasting effects by the two substances on recovery from desensitization emerged. Thirty seconds after the conditioning pulse, in the presence of Rp-cAMPS $(10 \mu \mathrm{M})$, the nicotine test current was $7 \%$, whereas in the presence of forskolin it was $48 \%$. Figure $5 C$ shows that on average for cells tested at $30 \mathrm{sec}$ intervals, application of forskolin $(10 \mu \mathrm{M})$ induced a small improvement in recovery from desensitization $(48 \pm 4 \%$ vs $35 \pm 6 \%$ at 30 sec with $p<0.05 ; 36$ and 44 sec time constant, respectively). Conversely, Rp-cAMPS reduced the rate of recovery from desensitization ( $18 \pm 2 \%$ at $30 \mathrm{sec} ; p<0.001 ; 60 \mathrm{sec}$ time constant). Like the result with staurosporine, recovery in the presence of Rp-CAMPS was incomplete, reaching $46 \%$ at 120 sec.

Because staurosporine can also block PKA activity (Hidaka and Kobayashi, 1992), experiments were performed to find out whether under the present conditions this substance acted on desensitization recovery via a combination of effects on PKC and PKA. For this purpose Rp-cAMPS $(10 \mu \mathrm{M})$ and staurosporine $(0.1 \mu \mathrm{M})$ were added to the patch pipette. The plot of Figure $5 C$ shows that combined application of these compounds elicited additive inhibitory effects on recovery $(p<0.0003,0.001$, and 0.003 at 30, 60, and $90 \mathrm{sec}$, respectively; $74 \mathrm{sec}$ time constant), suggesting that the action of staurosporine was not attributable simply to PKA inhibition. The only slight recovery of test currents after the combined treatment was not attributable to cell deterioration because no change in baseline current level appeared: partial recovery $(\sim 50 \%)$ of nicotine current amplitude was eventually obtained after 10 min (not shown).

\section{DISCUSSION}

The principal findings of the present study on rat chromaffin cells are that (1) large increases in $\left[\mathrm{Ca}^{2+}\right]_{i}$ per se did not promote desensitization of nAChRs and (2) activators of serine/threonine kinases or an inhibitor of phosphatase $2 \mathrm{~B}$ (calcineurin) hastened recovery from desensitization whereas kinase inhibitors produced an opposite effect. These data suggest that for neuronal nAChRs the recovery from desensitization rather than the actual desensitization process was regulated by their phosphorylation state.

\section{A role of $\left[\mathrm{Ca}^{2+}\right]_{i}$ in desensitization of neuronal $n A C h R s$}

On rat chromaffin cells a persistent rise in $\left[\mathrm{Ca}^{2+}\right]_{\mathrm{i}}$ has little effect on the onset and extent of desensitization but crucially determines recovery from it (Khiroug et al., 1997b). It seems possible, however, that such a large rise might downregulate receptor 


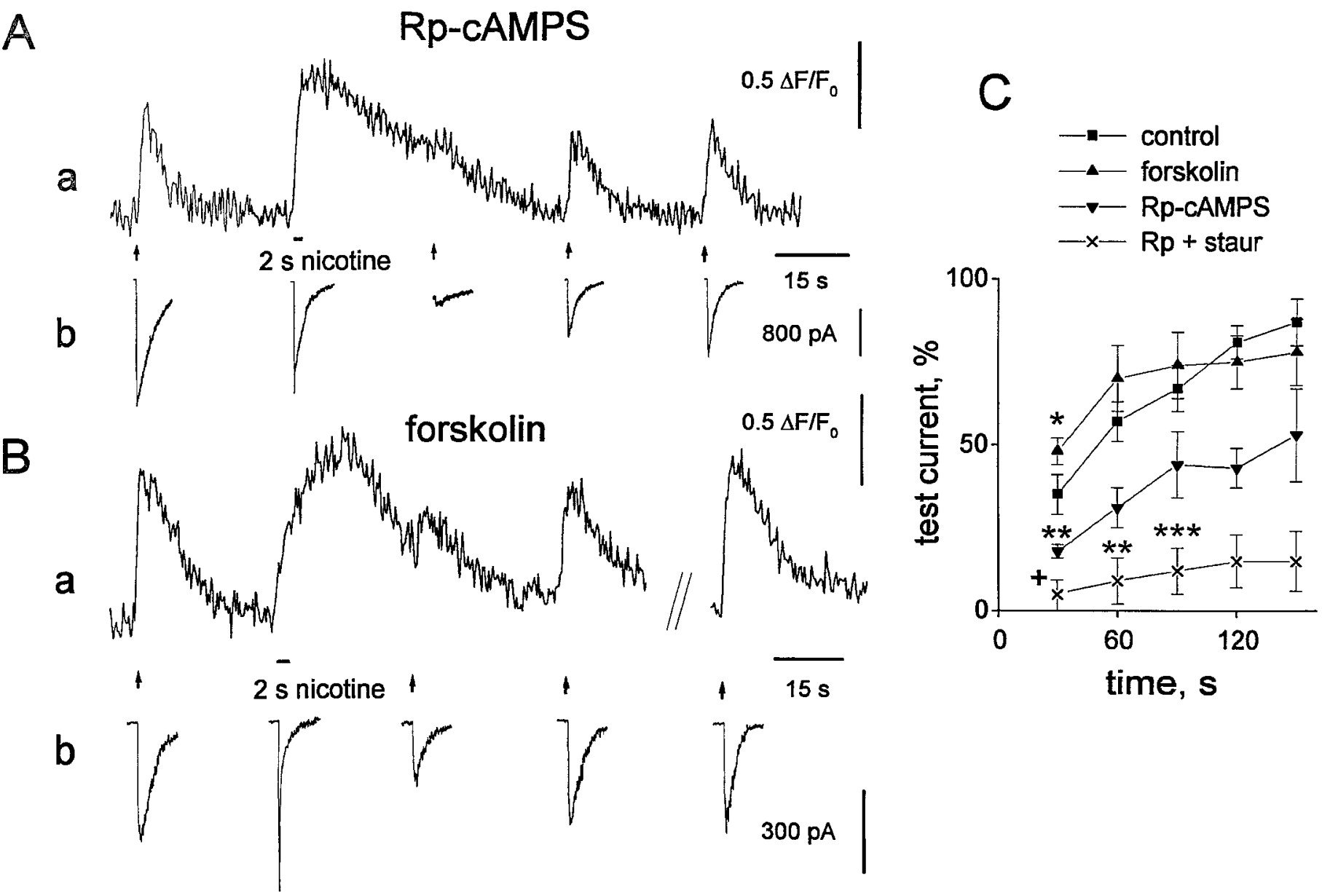

Figure 5. Action of the PKA inhibitor Rp-cAMPS or the adenylate cyclase activator forskolin on recovery from desensitization. Membrane currents $(b)$ and $\left[\mathrm{Ca}^{2+}\right]_{\mathrm{i}}$ transients $(a)$ are shown in $A$ and $B . A$, Standard protocol to induce desensitization applied to a cell patched with Rp-cAMPS (10 $\mu \mathrm{M})$-containing pipette reveals slow recovery. $B$, Opposite action of forskolin $(10 \mu \mathrm{M})$ consisting of acceleration of recovery under the same experimental protocol. $C$, Pooled data summarizing recovery time course from 5-10 cells in control (squares) or in the presence of forskolin (upward triangles), Rp-cAMPS (downward triangles), or mixture of Rp-cAMPS and staurosporine $[R p+$ staur $(100 \mathrm{nM})$; $\times]$. Note substantially slower recovery in the presence of both Rp-cAMPS and staurosporine. $+=p<0.0003 ;{ }^{*},{ }^{*}, * * *=p<0.05,0.001$, or 0.003 , respectively.

activity independently of desensitization: this issue was tested in the present investigation by observing the effects of large and sustained $\left[\mathrm{Ca}^{2+}\right]_{\mathrm{i}}$ transients (attributable to membrane depolarization or spontaneous occurrence) on nondesensitizing responses to nicotine. Because no significant change in nicotine currents was detected, we can infer that mere $\left[\mathrm{Ca}^{2+}\right]_{\mathrm{i}}$ elevation (even if comparable to the one induced by a conditioning pulse of nicotine) was insufficient to bring about any depression of nAChR. Thus, under the present experimental conditions of patch-clamp recording from cultured chromaffin cells, there was no evidence for a major, direct role of $\left[\mathrm{Ca}^{2+}\right]_{\mathrm{i}}$ in controlling the operation of neuronal nAChRs from the inner side of the cell membrane. In view of the fact that for other nAChRs phosphorylation has an important influence on desensitization (Huganir et al., 1986; Downing and Role, 1987; Hopfield et al., 1988), the potential contribution of various $\left[\mathrm{Ca}^{2+}\right]_{\mathrm{i}}$-dependent intracellular enzymes was explored by applying activators or inhibitors via the patch pipette.

\section{Onset and extent of desensitization are insensitive to pharmacological modulation of serine/threonine kinases or phosphatases}

None of the substances applied via the patch pipette seemed to exert nonspecific actions on $\mathrm{nAChR}$-mediated responses because no change in the current amplitude induced by 2 sec application of nicotine was observed. The onset and extent of desensitization, monitored in terms of time constant of current fade during $2 \mathrm{sec}$ nicotine application and attained current level near the end of this pulse, were not significantly altered by the group of activators and inhibitors of intracellular enzymes tested in the present study. This finding accords with analogous results from skeletal muscle nAChRs (Cachelin and Colquhoun, 1989). Because staurosporine, a broad spectrum inhibitor of kinases, did not enhance desensitization, it seems likely that there was little (if any) constitutively active serine/threonine kinase determining the onset and degree of desensitization under the present conditions. This view is reinforced by the similar lack of effect of phosphatase 1, 2 $\mathrm{A}$ and $\mathrm{B}$ inhibitors. Although these results do not exclude a role for other enzymes (for instance tyrosine kinase) (Swope and Huganir, 1994; Fuhrer and Hall, 1996), they accord with our previous observation that the onset of desensitization was independent of $\left[\mathrm{Ca}^{2+}\right]_{\mathrm{i}}$ variations (Khiroug et al., 1997b).

\section{Recovery from desensitization: intracellular modulation}

It is particularly important to note that none of these substances influenced the decay of the $\left[\mathrm{Ca}^{2+}\right]_{i}$ rise after $2 \mathrm{sec}$ application of nicotine (Table 1 ), because this parameter has been previously 
shown to be crucial for recovery from desensitization (Khiroug et al., 1997b). This result allowed us to exclude the possibility that any change in recovery from desensitization (observed after a certain substance was applied) was just secondary to a drugevoked modification in $\left[\mathrm{Ca}^{2+}\right]_{\mathrm{i}}$ dynamics.

The phorbol ester PMA, a selective PKC activator, facilitated recovery from desensitization, although it should be mentioned that complete recovery was not attained because test currents remained $\sim 20 \%$ smaller than controls before desensitization. Conversely, staurosporine depressed recovery only 1 min after the conditioning dose and prevented full return of the current amplitude. The insensitivity of the early recovery phase to staurosporine might suggest that the role of PKC in this process was delayed, perhaps because of the predominance of other intracellular enzymes. After 1-2 min, PKC was presumably fully activated, as indicated by a degree of similarity in recovery curves in control or PMA-treated cells. Staurosporine is a broad spectrum blocker of kinases, with PKC as its most sensitive target (Hidaka and Kobayashi, 1992). The final intracellular concentration of staurosporine in patch-clamped chromaffin cells is unknown, because some compartmentalization of this substance is likely to have taken place. Nevertheless, the depression of recovery by Rp-cAMPS, a selective inhibitor of PKA, was additive to the one by staurosporine, suggesting that staurosporine had not largely blocked PKA activity, even if this enzyme was only 10-fold less sensitive than PKC (Hidaka and Kobayashi, 1992). Furthermore, most intracellular messengers controlling this process must have been effectively eliminated by staurosporine and Rp-cAMPS, because poor recovery of nicotine currents was seen despite unchanged $\left[\mathrm{Ca}^{2+}\right]_{\mathrm{i}}$ dynamics and lack of evidence for cell deterioration. These observations thus suggest that both PKC and PKA activity facilitated recovery from desensitization. The effect of forskolin (which stimulates PKA activity via adenylate cyclase) accorded with this notion, although the limited degree of responsiveness to forskolin might have reflected already substantial activation of PKA under the present conditions.

On muscle nAChRs, a balance between PKC and calcineurin activities is thought to be essential to ensure recovery from desensitization (Hardwick and Parsons, 1996). Presumably a similar situation applies to chromaffin cell nAChRs, because the selective calcineurin inhibitor CC complex facilitated recovery whereas its inactive analog or the phosphatase 1 and $2 \mathrm{~A}$ inhibitor calyculin was ineffective. On the basis of these collective results, it is proposed that on chromaffin cells under control conditions, once nAChRs were desensitized by a large dose of nicotine the associated and persistent increase in $\left[\mathrm{Ca}^{2+}\right]_{\mathrm{i}}$ triggered at least two separate biochemical cascades: receptor phosphorylation to facilitate return to active conformation as well as receptor dephosphorylation to maintain desensitization. The opposing action between these two $\mathrm{Ca}^{2+}$-dependent enzymatic systems might fine-tune the ability of nAChRs to regain their sensitivity. To study this mechanism with improved temporal resolution, elevation (or buffering) of $\left[\mathrm{Ca}^{2+}\right]_{i}$ using UV light-sensitive caged compounds will be helpful.

More complex is the condition that develops after intracellular application of activators or inhibitors of these enzymes. In fact, even if the rate of $\left[\mathrm{Ca}^{2+}\right]_{\mathrm{i}}$ decay determines the time course of recovery from desensitization (Khiroug et al., 1997b), the simultaneous presence of high $\left[\mathrm{Ca}^{2+}\right]_{\mathrm{i}}$ and, for instance, PMA might have strongly biased the system toward phosphorylation, which was presumably supported by an ambient level of $\left[\mathrm{Ca}^{2+}\right]_{i}$, hence the dissociation between substantial recovery from desensitiza- tion and persistent elevation in $\left[\mathrm{Ca}^{2+}\right]_{\mathrm{i}}$. Along the same line, kinase inhibition by staurosporine might have prevented any significant receptor phosphorylation needed to ensure recovery from desensitization. Thus, even after $\left[\mathrm{Ca}^{2+}\right]_{\mathrm{i}}$ returned to baseline, responses to nicotine remained depressed. These observations make unlikely a direct role of free intracellular $\mathrm{Ca}^{2+}$ in recovery from desensitization, because by manipulating intracellular kinases the inverse relation between $\left[\mathrm{Ca}^{2+}\right]_{\mathrm{i}}$ and current recovery could not be maintained consistently.

\section{Phosphorylation of neuronal nAChRs: a process to control transmitter sensitivity}

The intracellular domains of transmembrane receptors for neurotransmitters such as GABA, glycine, or glutamate are readily phosphorylated, with consequent changes in their properties (for review, see Smart, 1997). Muscle-type nAChRs are also phosphorylated by various intracellular kinases, which have usually been shown to promote desensitization (for review, see Huganir and Greengard, 1990; Levitan, 1994) (but see Cachelin and Colquhoun, 1989). Conversely, in the case of neuronal nAChRs of rat chromaffin cells, their phosphorylation state appeared important in determining recovery from desensitization. The reason for this difference remains unclear. It should be noted that neuronal nAChRs are heterogenous (Role and Berg, 1996) and those on chromaffin cells comprise various heteromeric structures (Criado et al., 1992; Campos-Caro et al., 1997) that have not yet provided identification of the consensus sequences susceptible to distinct kinases. This complexity might contribute to the observation that PKC or PKA activators had similar effects on recovery of nicotine currents, perhaps because responses were mediated by receptors with different subunit composition and kinase sensitivity. It seems unlikely that homomeric $\alpha_{7}$ receptors were involved in the measured responses, because on chromaffin cells $\alpha$-bungarotoxin is ineffective in blocking inward current or $\left[\mathrm{Ca}^{2+}\right]_{\mathrm{i}}$ rises induced by nicotine (Fenwick et al., 1982; Vernino et al., 1994; Nooney and Feltz, 1995; Khiroug et al., 1997b). In summary then, the present study has provided novel evidence that on chromaffin cells the persistent elevation in $\left[\mathrm{Ca}^{2+}\right]_{i}$ determined recovery from desensitization of native nAChRs by influencing the balance between activation of intracellular serine/threonine kinases and calcineurin. Recombinant DNA techniques ought to help to identify the phosphorylation/dephosphorylation sites, although it should be mentioned that recombinant neuronal $\mathrm{nAChRs}$ of autonomic ganglia possess properties quite different from those of their native counterparts (Sivilotti et al., 1997).

Recent studies have also emphasized that recovery from desensitization of $5 \mathrm{HT}_{3}$ receptors (Boddeke et al., 1996) or capsaicin receptors (Koplas et al., 1997) is strongly dependent on their phosphorylation state. It therefore appears that distinct receptor systems are relying on the balance between phosphorylation and dephosphorylation to regain their agonist sensitivity.

\section{REFERENCES}

Amador M, Dani JA (1995) Mechanism for modulation of nicotinic acetylcholine receptors that can influence synaptic transmission. J Neurosci 15:4525-4532.

Berridge MJ (1997) Elementary and global aspects of calcium signalling. J Physiol (Lond) 499:291-306.

Boddeke HW, Meigel I, Boeijinga P, Arbuckle J, Docherty RJ (1996) Modulation by calcineurin of 5-HT3 receptor function in NG108-15 neuroblastoma $\times$ glioma cells. Br J Pharmacol 118:1836-1840.

Boyd ND (1987) Two distinct kinetic phases of desensitization of acetylcholine receptors of clonal rat PC12 cells. J Physiol (Lond) 389:45-67. 
Brandt BL, Hagiwara S, Kidokoro Y, Miyazaki, S (1976) Action potentials in the rat chromaffin cell and effects of acetylcholine. J Physiol (Lond) 263:417-439.

Cachelin AB, Colquhoun D (1989) Desensitization of the acetylcholine receptor of frog end-plates measured in a Vaseline-gap voltage clamp. J Physiol (Lond) 415:159-188.

Campos-Caro A, Smillie FI, Dominguez del Toro E, Rovira JC, VicenteAgullo F, Chapuli J, Juiz JM, Sala S, Sala F, Ballesta JJ, Criado M (1997) Neuronal nicotinic acetylcholine receptors on bovine chromaffin cells: cloning, expression, and genomic organization of receptor subunits. J Neurochem 68:488-497.

Chestnut TJ (1983) Two-component desensitization at the neuromuscular junction of the frog. J Physiol (Lond) 336:229-241.

Criado M, Alamo L, Navarro A (1992) Primary structure of an agonist binding subunit of the nicotinic acetylcholine receptor from bovine adrenal chromaffin cells. Neurochem Res 17:281-287.

D'Andrea $\mathrm{P}$, Thorn $\mathrm{P}$ (1996) $\mathrm{Ca}^{2+}$ signalling in rat chromaffin cells: interplay between $\mathrm{Ca}^{2+}$ release from intracellular stores and membrane potential. Cell Calcium 19:113-123.

Downing JEG, Role LW (1987) Activators of protein-kinase C enhance acetylcholine receptor desensitization in sympathetic ganglion neurons. Proc Natl Acad Sci USA 84:7739-7743.

Fenwick EM, Marty A, Neher E (1982) A patch-clamp study of bovine chromaffin cells and of their sensitivity to acetylcholine. J Physiol (Lond) 331:577-597.

Fuhrer C, Hall ZW (1996) Functional interaction of Src family kinases with the acetylcholine receptor in $\mathrm{C} 2$ myotubes. J Biol Chem 271:32474-32481.

Garcia-Guzman M, Sala F, Sala S, Campos-Caro A, Criado M (1994) Role of two acetylcholine receptor subunit domains in homomer formation and intersubunit recognition, as revealed by alpha 3 and alpha 7 subunit chimeras. Biochemistry 33:15198-15203.

Giniatullin R, Khiroug L, Talantova M, Nistri A (1996) Fading and rebound of currents induced by ATP on PC12 cells. Br J Pharmacol 119:1045-1053.

Hardwick JC, Parsons RL (1996) Activation of the protein phosphatase calcineurin during carbachol exposure decreases the extent of recovery from end-plate desensitization. J Neurophysiol 76:3609-3616.

Hidaka H, Kobayashi R (1992) Pharmacology of protein kinase inhibitors. Annu Rev Pharmacol Toxicol 32:377-397.

Hopfield JF, Tank DW, Greengard P, Huganir RL (1988) Functional modulation of the nicotinic acetylcholine receptor by tyrosine phosphorylation. Nature 336:677-680.

Huganir RL, Greengard P (1990) Regulation of neurotransmitter receptor desensitization by protein phosphorylation. Neuron 5:555-567.

Huganir RL, Delcour AH, Greengard P, Hess GP (1986) Phosphorylation of the nicotinic acetylcholine receptor regulates its rate of desensitization. Nature 321:774-776.

Jones MV, Westbrook GL (1996) The impact of receptor desensitization on fast synaptic transmission. Trends Neurosci 19:96-101.

Katz B, Thesleff S (1957) A study of the "desensitization" produced by acetylcholine at the motor end-plate. J Physiol (Lond) 138:63-80.
Khiroug L, Giniatullin R, Talantova M, Nistri A (1997a) Role of intracellular calcium in fast and slow desensitization of $\mathrm{P}_{2}$-receptors in $\mathrm{PC} 12$ cells. Br J Pharmacol 120:1552-1560.

Khiroug L, Giniatullin R, Sokolova E, Talantova M, Nistri, A (1997b) Imaging of intracellular calcium during desensitization of nicotinic acetylcholine receptors of rat chromaffin cells. $\mathrm{Br} \mathrm{J}$ Pharmacol 122:1323-1332.

Koplas PA, Rosenberg RL, Oxford GS (1997) The role of calcium in the desensitization of capsaicin responses in rat dorsal root ganglion neurons. J Neurosci 17:3525-3537.

Levitan IB (1994) Modulation of ion channels by protein phosphorylation and dephosphorylation. Annu Rev Physiol 56:193-212.

Magazanik LG, Vyskocil F (1970) Dependence of acetylcholine receptor desensitization on the membrane potential of frog muscle fiber and on the ionic changes in the medium. J Physiol (Lond) 210:507-518.

Manthey AA (1966) The effect of calcium on the desensitization of membrane receptors at the neuromuscular junction. J Gen Physiol 49:963-975.

Miledi R (1980) Intracellular calcium and desensitization of acetylcholine receptors Proc R Soc London B Biol Sci 209:447-452.

Minta A, Kao JP, Tsien RY (1989) Fluorescent indicators for cytosolic calcium based on rhodamine and fluorescein chromophores. J Biol Chem 264:8171-8178.

Mulle C, Choquet D, Korn H, Changeux J-P (1992) Calcium influx through nicotinic receptor in rat central neurons: its relevance to cellular regulation. Neuron 8:135-143.

Nooney JM, Feltz A (1995) Inhibition by cyclothiazide of neuronal nicotinic responses in bovine chromaffin cells. $\mathrm{Br} \mathrm{J}$ Pharmacol 114:648-655.

Role LW, Berg DK (1996) Nicotinic receptors in the development and modulation of CNS synapses. Neuron 16:1077-1085.

Sivilotti LG, McNeil DK, Lewis TM, Nassar MA, Schoepfer R, Colquhoun D (1997) Recombinant nicotinic receptors, expressed in Xenopus oocytes, do not resemble native rat sympathetic ganglion receptors in single-channel behaviour. J Physiol (Lond) 500:123-138.

Smart T (1997) Regulation of excitatory and inhibitory neurotransmittergated ion channels by protein phosphorylation. Curr Opin Neurobiol 7:358-367.

Swope SL, Huganir RL (1994) Binding of the nicotinic acetylcholine receptor to $\mathrm{SH} 2$ domains of Fyn and Fyk protein tyrosine kinases. J Biol Chem 269:29817-29824.

Vernino S, Rogers M, Radcliffe KA, Dani JA (1994) Quantitative measurement of calcium flux through muscle and neuronal nicotinic acetylcholine receptors. J Neurosci 14:5514-5524.

Yakel JL (1997) Calcineurin regulation of synaptic function: from ion channels to transmitter release and gene transcription. Trends Pharmacol Sci 18:124-134.

Zhou Z, Neher E (1993) Calcium permeability of nicotinic acetylcholine receptor channels in bovine adrenal chromaffin cells. Pflügers Arch 425:551-557. 